child health, nutrition, mental health, housing, animal health, the prevention of disease, municipal and industrial health, etc. A number of excursions have been planned, among them being visits to the Elan Valley, the Cotswolds (Burford, Broadway, Fairford, the Rollright Stones, etc.), Stratford-onAvon (including a performance at the Memorial Theatre), and Bath (via Wells, Glastonbury and Cheddar). The cost of the School will be $£ 1616 s$., including full board at the College, and it is jointly sponsored by the Association of Women Science Teachers, 11 Fillebrook Hall, Fillebrook Road, Leytonstone, E.11, and the British Social Biology Council, Tavistock House South, Tavistock Square, W.C.1, from whom further information can be obtained.

\section{World Metallurgical Congress in Detroit}

A World Metallurgical Congress, sponsored by the American Society for Metals, will be held in Detroit, Michigan, during October 15-19. Dr. Zay Jeffries, former president of the American Society for Metals and former vice-president of the General Electric Co., will be director-general. Simultaneously with the Congress the Thirty-Third Annual National Metal Congress and National Metal Exposition will be held in Detroit during October 11-20. Invitations are being sent out to industrial countries to send national teams made up of technologists, men of science, production executives, and sales engineers in the metal-producing and -fabricating industries. These representatives will meet in New York City on September 10 and will be divided into groups according to the interest of the individual. The groups will then go on guided tours for three weeks, visiting important plants and institutions, before finishing up at Detroit for the Metal Congress and Exposition. Details of the members of national teams should be completed by May I. At the World Congress the programme on the exchange of information and latest industrial techniques will be divided into the following headings: steel making and refining; preparation of metals for economic fabrication; fabrication of metals; research in metals ; marketing ; national engineering societies; and metallurgical instruction at university and postgraduate level. Discussion will also take place on the conservation, utilization and substitution of strategic metals. The official langrages of the Congress will be English and French. Further details can be obtained from W. H. Eisenman, secretary of the American Society for Metals, 7301 Euclid Avenue, Cleveland 3, Ohio.

\section{Conference on Automatic Control}

A conferfance on "Automatic Control" is to be held at the College of Aeronauties, Cranfield, Bedfordshire, during July $16-21,1951$. The papers and discussions, which should be of particular interest to engineers, physicists and mathematicians concerned with the thenry, design, production and testing of automatic control systems, and their use in industry, will cover the following main topics: automatic control sy'stems (general theory and problems of synthesis); servo control systems (non-linearities); process control, including inter-relation with servo control; and the human operator. Other more specialized topies may be insluded, and there will also be provision for a limited display of automatic control apparatus. The conference is sponsored by the Department of Scientific and Industrial Research, and the organizing committee is under the chairmanship of Prof. A. Tustin, professor of electrical engin. eering in the University of Birmingham. The accommorlation at Cranfisld ran only hold about 250 , and it will be necessary to limit attendance to leading workers in the field of automatic control. Further information can be obtained from the Secretary of the Organizing Committee, Conference on Automatic Control-1951, D.S.I.I., Charles House, Regent Street, London, S.W.1.

\section{Human Factors in Equipment Design}

A sxMposium on human factors in equipment design will be held by the Ergonomics Research Society during April 18-21 in the University of Birmingham. Membership of the symposium will be open to anyone, whether a member of the Society or not, who is interested in the application of anatomical, physiological and psychological knowledge to the design of equipment. After the opening session on April 18, the morning and afternoon sessions on April 19 and 20 will be devoted to, respectively: physical anthropometry and problems of seating and posture, visual and auditory displays, muscular force and work, and speed of performance. There will be a short final session on April 21, at the end of which Sir Frederic Bartlett will give a concluding address. Accommodation for those attending the symposium will be provided in one of the hostels of the University. Further inquiries should be addressed to the symposium secretary, Miss B. G. Murrell, 219 Cromwell Mansions, Cromwell Road, London, S.W.5.

\section{Announcements}

THE Section of Science of the Royal Netherlands Academy of Sciences and Literature has awarded the Leeuwenhoek Medal to Prof. S. A. Waksman, professor of soil microbiology in Rutgers University, New Brunswick, N.Y. This Medal, which is in gold, is awarded every ten years to commemorate the discovery of micro-organisms by Antony van Leeuwenhoek.

Prof. Gaston Dupouy, honorary dean of the Faculty of Sciences of the University of Toulouse and director since 1950 of the Centre National de la Recherche Scientifique, has been elected a nonresident member of the Paris Academy of Sciences in place of the late E. Cotton. Prof. Dupouy is well known for his experimental and theoretical research work in magnetism and magneto-optics and also in electron optics, including the electron microscope.

THE Commission Internationale des Industries Agricoles has issued recently a number of bibliographies dealing with mineral nutrition of plants, influence of ultra-violet radiation on amino-acids and proteins, corrosion of metals by sea-water, marking fish for migration studies, artificial ageing of alcoholic liquors, etc. Most of the abstracts are in English or French. Copies of these bibliographies are available on loan in Great Britain, on application to : Research Department, Saml. Hanson and Son, Ltd., Toddington, Cheltenham, Glos. No charge will be made beyond that necessary to cover the cost of packing and postage. Inquiries for the purchase of the bibliographies should be addressed to C.I.I.A., 18 Avenue de Villars, Paris, VIJe.

Erratum. In the communication entitled "Folic Acid, Vitamin $\mathrm{B}_{12}$ and Nucleic Acid Synthesis in Lactobacillus casei" by D. V. Rege and Dr. A. Sreenivasan published in Nature of December 30, p. 1117, the quantities of supplement mentioned in col. 1 of the table should be "mugm.", not " $\mu \mathrm{gm} . "$ as printed. 